\title{
FRUGAL INNOVATION CORE COMPETENCIES TO ADDRESS GLOBAL SUSTAINABILITY
}

\author{
RADHA R. BASU \\ Santa Clara University \\ Santa Clara, California, U.S.A. \\ rbasu@scu.edu
}

PREETA M. BANERJEE

Brandeis University

Waltham, Massachusetts, U.S.A.

pbanerjee@deloitte.com

\author{
ELIZABETH G. SWEENY \\ Santa Clara University \\ Santa Clara, California, U.S.A. \\ esweeny@scu.edu
}

\begin{abstract}
The call for global sustainability is echoed by societal, environmental, and economic needs across the globe. In answering this call, a design innovation process that properly considers the needs and context of citizens in the developing world is necessary in order to develop appropriate, adaptable, affordable, and accessible solutions, products and services. This process, called "Frugal Innovation," is rapidly becoming a standard against which sustainable solutions are assessed. Through an exploration of Frugal Innovation Core Competencies (Frugal Innovation Lab, Santa Clara University), and corresponding case studies of field solutions, a model is presented to begin sustainably addressing global human needs.
\end{abstract}




\section{INTRODUCTION: A CALL FOR GLOBAL SUSTAINABILITY}

Global sustainability is intimately related to societal, environmental, and economic equity. When seeking sustainable solutions to global challenges, it is critical that all inhabitants be treated with equity. From a moral or a business standpoint, equity is inextricably linked to sustainable, globalized solutions. World hunger, poverty, social injustice, and general lack of resources that afflict billions of people are all important aspects to consider when ideating for large-scale sustainability solutions.

In answering the call for global sustainability, we present the concept of Frugal Innovation. Frugal Innovation is a design innovation process in which the needs and context of citizens in the developing world are put first in order to develop appropriate, adaptable, affordable, and accessible services and products for emerging markets. Social enterprises are built around the idea of Frugal Innovation and entrepreneurship to solve sustainability challenges in Bottom of the Pyramid (BOP) markets. In the past, the $\mathrm{BOP}-$ or those 4 billion people who live on less than an average of $\$ 5$ a day-have not been the focus of innovative energies. Frugal Innovation inverts conventional views to empower and enable the BOP (see Figure 1). The balance of economic power is expected to shift dramatically over the next half century, with fast-growing emerging market economies accounting for an ever-increasing share of global output (Johansson et al., 2012). The United States is expected to cede its place as the world's largest economy to China as early as 2016. India's GDP is also expected to pass that of the United States over the long term. These two Asian giants combined will soon surpass the collective economy of the G7 nations. Fast-aging economic heavyweights, such as Japan and the Euro area, will gradually lose ground on the global GDP table to countries with younger populations like Indonesia and Brazil. Given this seemingly indisputable trend, Frugal Innovation has blossomed to target these underserved populations, encouraging entrepreneurship and sustainable growth for all participants. Most developed countries have failed to embrace a frugal approach in the past, and the world is seeing resource shortages, environmental damage, and a plethora of other negative consequences as a result of the conventional approaches to product and service innovation. 


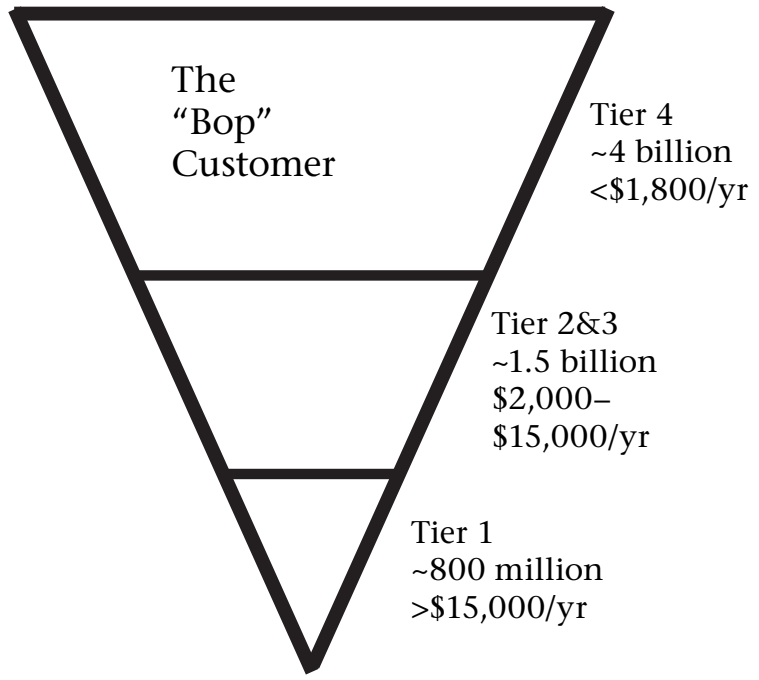

Figure 1: Inverted Pyramid

The 10 Core Competencies of Frugal Innovation were developed by the Frugal Innovation Lab at Santa Clara University. The 10 Core Competencies are:

\section{Ruggedization}

2. Lightweight: portable for varying transportation options

3. Mobile Enabled Solutions: connectivity anytime, anywhere

4. Human Centric Design: easy-to-use, intuitive designs that require little to no prior knowledge or training to utilize

5. Simplification: minimalist features and functional requirements

6. New Distribution Models: non-conventional channels and access.

7. Adaptation: leveraging existing products, inputs and services 
8. Use of Local Resources: sourcing without importing equipment or materials

9. Green Technologies: powered by renewable resources

10. Affordability: low input and operation costs

These 10 core competencies are rapidly becoming a standard for developing appropriate, affordable, adaptable, and accessible solutions and assessing an innovation's adequacy and readiness for successful market penetration. The competencies form the basis for making powerful contributions to a more global sustainability, including greater inclusiveness and social equity. Their role in evaluating new technologies and processes for consumers in emerging economies will enable them to become increasingly important and influential in the global market landscape within the next 5-10 years.

To illustrate each of these competencies, we present brief case studies that depict tangibly how each one of the competencies has been applied to product and service innovation. These innovations were all created with the intention of developing sustainable solutions that address immediate needs while integrating a long-term outlook. When scaled, these solutions can contribute to a more sustainable world by aiding the efforts to end global poverty, world hunger, and social injustice, and to protecting the capacity of the planet to support our own and other species. Initially, direct benefit will be readily apparent; however, the potential for far-reaching, positive domino effects as a result of the proper implementation of these innovations is also tremendous.

The following cases explain the process of generating positive change via Frugal Innovation; we hope they will also motivate readers to take action by engaging with-and embracing - the opportunities to make similar innovative and valuable contributions in emerging markets. Frugal Innovation prioritizes the needs of all stakeholders of business, including the end consumers, the environment, and future generations. By focusing on how we produce and consume, social, environmental, and economic sustainability can become a global reality.

\section{THE 10 CORE COMPETENCIES OF FRUGAL INNOVATION}

The importance of Frugal Innovation lies partly in its ability to be economically efficient under conditions of severe scarcity. Frugal Innovation opens a door for developing country entrepreneurship and innovation through its recognition of, and emphasis on, the im- 
portance of home-country involvement. By restructuring traditional business models, designs that are frugally innovated meet demand that is already present, ensuring a certain amount of viability from the initiation of a project (Zeschky, Widenmayer, \& Gassman, 2011). Frugal Innovation uses innumerable aspects of the domestic marketplace to generate affordable and applicable innovations for use by consumers, including those who are at the BOP.

\begin{tabular}{|c|c|c|}
\hline Characteristics & Frugal Innovation & $\begin{array}{c}\text { Conventional } \\
\text { Innovation }\end{array}$ \\
\hline Driver & What do they need & $\begin{array}{c}\text { What would be nice } \\
\text { to have }\end{array}$ \\
\hline Process & Bottom-up & Top-down \\
\hline Core Capabilities & $\begin{array}{c}\text { Functionality- } \\
\text { rugged, lightweight, } \\
\text { adaptable, simple }\end{array}$ & Desirability and design \\
\hline Location & $\begin{array}{c}\text { Developing, Emerging } \\
\text { Markets }\end{array}$ & Developed Markets \\
\hline
\end{tabular}

Figure 2: Alternative Models of Innovation

The idea of "Reverse Innovation" is a crucial one to consider in responding to global sustainability goals. While related to Frugal Innovation, Reverse Innovation is the concept of taking ideas that have been developed in an emerging market and coaxing them to flow uphill to Western markets. Implicitly, Reverse Innovation can be seen as benefiting primarily consumers in developed countries who benefit from less expensive products and services pioneered in developing countries. Frugal Innovation emphasizes how innovations can be created for resourceconstrained environments, the direct benefits to BOP members, and the role that can be played by the populations at the BOP. Those BOP innovators seek opportunities for growth and advancement and become an important source of the innovations from which they will benefit and that may also be transferred to more developed countries. Given this potential for knowledge and technology acquisition sourced from the developing world, developed countries' business leaders have begun to adjust their existing business models to incorporate value-adding intelligence from these emerging economies (Baiyere, 2011).

Health care is a prime example of how options generated for emerging markets can play a significant role in reshaping how health care is administered in developed nations. For instance, such reverse innovations include GE's electrocardiograph (ECG) machine, which typically weighed 15 lbs. and cost $\$ 5.4$ million. In 18 months, GE was able to 
engineer the same functionalities to fit into a portable handheld device for about $60 \%$ of its wholesale cost. Combining their technical knowhow with existing parts, GE engineers were able to adapt a printer that is used in bus terminal kiosks across India to serve the needs of the new ECG machine. The net effect is a reduction from $\$ 2,000$ to $\$ 800$ for an ECG machine, which translates to under $\$ 1$ per patient per scan. This lower cost ECG is not only relevant to the audience that it was developed for-expanded access to affordable ECGs in the developed world is critical as well. There is a broadening two-way avenue of innovative ideas being built between the developed and developing world that holds the potential to elevate both in a positive direction.

Generally speaking, developing countries have lower living standards, less developed industrial bases, and a low Human Development Index (HDI) when compared with developed countries (Sullivan \& Sheffrin, 2003). Populations in developing countries have restricted access to products and processes that are readily available in developed countries, and for many reasons, including general misconceptions and immense market barriers (Prahalad, 2005). Addressing market demand through a Frugal Innovation approach improves BOP living conditions, creates new sources of growth and cost-saving opportunities, and provides access to innovation (Hart \& Christensen, 2002). Frugal Innovation has the potential to elevate humanity as a whole by giving all individuals opportunities to be entrepreneurs and value-demanding consumers at the same time.

Given that global sustainability is so entwined with equity, it is significant that Frugal Innovation is so focused on inclusive innovation (defined as the inclusion of fundamental social responsibilities in strategy and operations management [Nijhof, Fisscher, \& Looise, 2002]). In other words, Frugal Innovation has the potential for inclusiveness, starting with the area from which it originates. Innovation is truly inclusive when it is intended for the benefit of people universally, and is exclusive when it is aimed only at a particular segment of the population-i.e., a specific socioeconomic group (Prahalad \& Mashelkar, 2010). Examples such as Gandhian engineering follow the purpose of "more from less for many" by moving from "low price, low performance" to "low price, high performance" (Altenburg \& Lundvall, 2009). Alternately, Jugaad engineering focuses on utilizing makeshift materials that are available in the context of extremely limited resources (Tiwari \& Herstatt, 2012).

Frugal Innovation is readily apparent in the 10 cases presented below. All of them are true examples of progress toward global sustainability, with Frugal Innovation lending an important helping hand in the success of the enterprises described therein. 


\begin{tabular}{|c|c|c|c|c|}
\hline $\begin{array}{c}\text { Key } \\
\text { Concept }\end{array}$ & Author(s) & Year & Example & $\begin{array}{c}\text { Innovation } \\
\text { Outcome }\end{array}$ \\
\hline $\begin{array}{c}\text { Reverse } \\
\text { Innovation }\end{array}$ & $\begin{array}{c}\text { Govindarajan } \\
\text { \& Ramamurti }\end{array}$ & 2011 & GE's ECG & $\begin{array}{c}\text { Add bells and whistles } \\
\text { to developing country } \\
\text { innovation that } \\
\text { competes in developed } \\
\text { countries }\end{array}$ \\
\hline $\begin{array}{c}\text { Gandhian } \\
\text { Engineering }\end{array}$ & $\begin{array}{c}\text { Prahalad \& } \\
\text { Mashelkar }\end{array}$ & 2010 & $\begin{array}{c}\text { Tata's } \\
\text { Nano }\end{array}$ & $\begin{array}{c}\text { Break down a complex } \\
\text { process/product and } \\
\text { rebuild in the most } \\
\text { economical way }\end{array}$ \\
\hline Jugaad & $\begin{array}{c}\text { Radjou, } \\
\text { Prabhu, \& } \\
\text { Ahuja }\end{array}$ & 2012 & $\begin{array}{c}\text { YES } \\
\text { BANK's } \\
\text { CAT }\end{array}$ & $\begin{array}{c}\text { Innovate with an eye } \\
\text { toward economical } \\
\text { andiency but also social } \\
\text { and environmental } \\
\text { bottom-lines }\end{array}$ \\
\hline
\end{tabular}

Figure 3: Frugal Innovation Models

\section{CORE COMPETENCIES \& CASE STUDIES}

Ruggedization: designed for harsh physical environments (e.g., heat, moisture, pests)_ToughStuff: Durable Solar Panel Charging System

The founders of ToughStuff International, Andrew Tanswell and Adriaan Mol, were inspired to help low-income families in the developing world by creating technologies that would assist in eliminating energy poverty (ToughStuff, 2010). ToughStuff's various solar-powered products, like its solar panel charging system, provide accessible, inexpensive solutions to energy poverty and allow for a better standard of living. Human development and emergency relief are two particularly important areas of focus for ToughStuff, and their products have been extremely effective in aiding progress in both arenas.

The solar panel charging system that ToughStuff developed can power LED lamps, mobile phones, and radios (Marlow, 2009). The system not only eliminates the recurring cost necessary to charge these critical, livelihood sustaining devices, but also the extensive time that is necessary to travel to charging stations. Able to charge at night from energy gathered and stored during sunlight hours, capable of withstanding extreme temperatures, and tested in deplorable conditions, the system has proven to be incredibly durable in all environments. Developing 
world economies are fully able to use ToughStuff's systems reliably, easily, and effectively.

Engineering these solutions to be rugged required a conscious effort. Design and materials both contribute to the system's ability to operate in extreme environments. A thin sheet of amorphous silicon that uses sunlight to generate electricity makes the product both nearly indestructible, resulting in minimal maintenance costs, and incredibly easy to use, making it easier to market to lower income consumers (Trickle Out Project, 2012). The solar panels are flexible, waterproof, and relatively small, all of which address target customers' needs. These aspects are the essence of Frugal Innovation at its very core.

While ToughStuff has not encountered many road blocks in the development of its systems, ideas on how to disseminate their product in targeted areas of high need have been more challenging. However, despite various barriers to entry, over 125,000 units were sold in the first two months following the product's introduction, and it is now sold in more than 25 African countries (Ashden Award Judges, 2011). A large factor in ToughStuff's success has been the knowledge that its products can withstand the tribulations of the environments for which they were designed.

Lightweight: portable for varying transportation options-Cisco and NetHope: Emergency NetReliefKit

Working together, NetHope and Cisco have developed an emergency NetReliefKit (NRK), which can best be thought of as a "communications hub in a box" for NGOs operating in the field. The kit provides both voice communication and Internet links via satellite, and can be powered solely by a car battery. With built-in $\mathrm{Wi}-\mathrm{Fi}$, it is possible for a single NRK to effectively serve an entire facility. This has proven to be of incredible benefit during natural disasters by helping victims in remote areas (Musich, 2007), and is made possible by the NRK's light weight and consequent ability of NGOs to transport it easily.

One NRK contains all the equipment needed to coordinate the transport of large groups of people from one location to another in the event of an emergency, yet still fits in a backpack or small suitcase (Peck, 2010). It includes a Broadband Global Area Network (BGAN) satellite terminal, a fold-flat 48-watt solar power kit, a small laptop, an 8-hour battery, a carrying case, various cables, power adapters, and controllers. While it was designed with emergency relief in mind, some NGOs have adopted 
the NRKs because of their incredible versatility and convenience for all communications needs. The NRK has revolutionized the way NGOs are able to operate on a day-to-day basis.

Given the quantity of equipment condensed into one unit, ensuring that the NRK was lightweight was a challenge (Wavelength, 2009). However, the joint experiences of both partners allowed for a progressive design process. NetHope, a nonprofit association of more than 25 NGOs (including Red Cross, World Vision, and Mercy Corps), relies on networking technology and Internet-based applications to keep in contact with each other during international emergencies, coordinate their responses more accurately, and quickly gather and disseminate critical information. Cisco in turn relies on networking technologies in an enterprise-wide fashion to ensure the safety of its employees on a global scale.

NRKs fuse these two areas of expertise together into a highly functional, four pound device that brings the larger world to the most remote and disconnected places on the globe (Nunziata, 2010). Units have already been critical in first response for disaster relief efforts in developing countries that have suffered major crises-the earthquakes in Haiti and Chile, and the cyclone that hit Bangladesh are three examples (Carless, 2007).

\section{Mobile Enabled Solutions: connectivity and effective instrumentation- Kopo Kopo: Mobile Money Platform}

The US-based software company Kopo Kopo partnered with Hope Micro and Splash Mobile Money in East Africa to invent a mobile money platform that allows customers to use mobile money services (Kopo Kopo, 2011). It is through this service that customers of the top three mobile networks can load money onto their mobile devices and send money, pay bills, withdraw money, and buy goods. These services release consumers from the constraints of having to travel long distances for financial transactions rather than investing their time in activities that will generate income for them. To do so, the services make use of a resource that already exists locally-mobile phones.

The Executive Director of Hope Micro, SD Kanu, realized that his customers were struggling with the opportunity cost of leaving their businesses for up to a full day to make payments for his mobile services (Microfinance Africa, 2011). The mobile money platform makes use of both Hope Micro and Splash Mobile Money services and is very conve- 
nient for consumers. Kopo Kopo incorporates the transactions of these customers into its accounting software to enable analysis of buying trends, and sends SMSs to interact with customers. Though its target is East Africa, Kopo Kopo intends to expand its service outside of SubSaharan Africa where competition is minimal (Sandell, 2012).

The Kopo Kopo mobile money platform has done very well in Sierra Leone, Kenya, and the rest of East Africa. The platform is becoming a disruptive technology for traditional currency as more customers are turning to this mobile money service. Despite its success, however, Kopo Kopo has been led to develop plans for market expansion to various other locations due to extreme competition from other mobile money service providers. Kopo Kopo estimates that the market for mobile money systems will be roughly $\$ 630$ billion by 2014 (Sinsky, 2011).

Human Centric Design: easy-to-use, intuitive designs that require little to no prior knowledge or training to utilize-Naandi: Jerry Can for Safe Water Program

Naandi, a charity working towards better health, basic education, and sustainable livelihoods for underprivileged people, has developed a Community Services Safe Water Program that allows villagers to drink and use clean water on a daily basis. By setting up a system that delivers safe drinking water at relatively low cost, villagers in Andhra Pradesh (Southeast India) are able to take responsibility for their attainment of clean water via an infrastructure that is easy-to-use. The jerry-can style container is a critical part of this infrastructure for clean water, as are the additional programmatic elements of the Naandi system that make the proposed solutions sustainable ones (Matthews, 2008).

To create a long-term reduction in exposure to environmental risks that lead to waterborne diseases, it is essential to market the importance of safe water. To that end, Naandi has developed intensive campaigns on health and personal hygiene to educate rural communities on the need to store water carefully, and to follow sanitation practices that avoid contaminating water resources. By influencing the integration of safe water practices into conventional behaviors, demand is created in other villages for adopting the SafeWater Program, which results in spreading the program to those new communities. Naandi also encourages the use of food-grade 20-liter jerry cans which they sell to customers at cost ( $\sim 150$ rupees or about \$3). In some cases, Naandi will offer an installment payment plan for the jerry can to ease the upfront cash requirement (William Davidson Institute, 2009). 
Each safe water operation employs a Safe Water Promoter (SWP), typically a woman from the local village community, who ensures that the villagers are aware of the services offered and who encourages transition to practices that make clean drinking water available. SWPs are also responsible for promoting hygienic sanitation practices among villagers through an Information, Education, and Communication campaign (IEC). When combined, these programs-SWP and IEC-develop a community-scale water infrastructure in which villagers have access to clean water at reasonable prices. In 2010, Naandi Community Water Services was present in over 400 villages, providing safe drinking water to 2.4 million people and distributing about 30 million liters each month at only $\$ 0.2$ cents per liter (Vousvouras \& Heierli, 2010). The programmatic and technological elements of Naandi's innovative approach are human-centric from every angle.

\section{Simplification: minimalist features and functional requirements-TATA Chemical: Rice Husk Water Filter}

In 2006, an innovation team started by R. Gopalakrishnan, the VP of Tata Chemicals, set out to develop a water purifier that was accessible, inexpensive, and highly effective (Lavallee \& Veach, 2010). What emerged out of this team's collaboration was the Tata Chemical rice husk water filter (Swach) which purifies water without electricity in an inexpensive manner, making drinking water safe and accessible to households that have no access to power (Subbu, 2009).

While the technology was based on previous water-purifiers (making this water purifier an example of adaptability as well; see core competency \#7), the team aimed to make it the "world's lowest-cost water purifier." Inspired by Edison's light bulb, the water purifier is made up of a composite of rice-husk ash and nano-silver particles, which together inhibit bacterial growth (Chang, 2010). It has a cartridge with a fuse that prevents water from passing through once the purifying capacity limit is reached, making it straightforward for users to generate safe water. The purifier is simple, makes use of local resources in harmony with hightech, and is easy to use-a highly relevant innovation.

The water filter originated from and benefits poor households in India, and thus required the following elements: ease of assembly, ease of maintenance (filter replacement), high usability, reliability, and acceptability. Launched in December 2009, the sea-green filters sold over 400,000 units in India in the first two years. Current plans exist for reaching other markets such as Africa, Southeast Asia, and Latin America (Singh, 2011). 


\section{New Distribution Models: non-conventional channels and access- Solar Sister: Avon Style Solar Product Distribution}

Solar Sister's Avon-style solar product distribution is an innovative method of spreading solar technology to benefit communities and simultaneously empower the women who are trained to participate. The business model provides rural customers with solar products to which they would otherwise not have access. It is a revolutionary approach to energy distribution in Africa as well as in other parts of the globe.

Katherine Lucey, the founder and CEO of Solar Sister, sought to decrease energy poverty in Africa while enabling rural women to develop economically (Huffington Post, 2011). Other business models did not account for the highly rural nature of these targeted areas, and lack of existing infrastructure did not allow for the sharing of technology, goods, services, or education. Lucey's development of this re-thought distribution model creates an avenue for rural women to network, spread information to their communities, and reduce energy poverty in the process (Misra, 2011).

Inspired by the Avon style of delivering products to local customers through fellow community members, women are trained and provided with an inventory of solar technology which they sell in rural regions (Making It, 2011). This system addresses many challenges at once: it creates an efficient and sustainable delivery system, promotes technology innovations, reduces the gender-technology gap, and makes women a key factor in entrepreneurial livelihood development (Solar Sister, 2012).

Adaptation: leveraging existing products, inputs and services-Awaaz. De: Voice Message Board for Education

Awaaz.De (which means "Give Your Voice") is a software platform that leverages low-end mobile phones and Internet access for aggregating, responding to, and routing voice messages. Created by Neil Patel and Tapan Parikh for use in India, Awaaz.De shares information through voice content and provides services that overcome language barriers and literacy constraints (Neil, 2011). Awaaz.De provides services such as interactive voice response voting, data collection, surveys, polling, access to mobile social networks, peer-to-peer information resources, and information databases-all on phones that are readily accessible.

The Awaaz.De platform exemplifies several core competencies, including use of local resources, human-centric design, and adaptation. The platform was developed from an existing technology that had been developed by Avaaj Otalo (AO). AO provided services for farmers to access 
relevant and timely agricultural information over their mobile phones. Developed as a collaboration between UC Berkeley School of Information, Stanford HCI Group, and the IBM India Research Laboratory and Development Support Center (DSC), AO sought a highly relevant communications service for rural farmers (Heatwole, 2011). Using just mobile phones and (even intermittent) Internet access, both $\mathrm{AO}$ and Awaaz.De have been able to focus on the essence of problems which their target communities face. Awaaz.De re-tasks AO technology to support a customized set of voice message boards with configurable posting and browsing settings.

Complementing their voice interface is a web-based administration interface that allows for the creation of sub-forums around specific topics that are of particular relevance to users. Community managers-typically members of a local organization that have access to the Internet-use the Awaaz.De interface to moderate message boards, annotate voice messages with author information and content tags, route messages to responders, and broadcast messages to reach wider audiences. An integration of existing technologies occurred between information pull voice forums and information push broadcasting in order to reach broader audiences. The "Internet for a few, voice for the rest" model reflects a now common scenario for rural information delivery systems.

The open-ended structure of the Awaaz.De platform allows for continued adaptation by different organizations that have followed in their footsteps as they had done with AO's platform. As of 2011, Awwaz.De served over 100,000 calls from more than 10,000 unique callers, and catered to 8 social development organizations and enterprises working in areas such as agriculture, education, women's empowerment, labor rights, and rural product manufacturing/distribution across 6 states in India (Devi, 2012). The applications of such a service are nearly limitless, providing another reason to describe the innovation as being adaptable.

Use of Local Resources: Sourcing without importing equipment or materialsHusk Power Systems: Rice Husk Gasification

Husk Power Systems (HPS) is a social enterprise that has developed a process to generate clean, safe, and efficient electricity by sourcing a local waste-rice husks. Rice husks are a waste product of rice hullers, machines that separate the husks as chaff from rice, which is a staple food in the regions where HPS operates. It is estimated that 4 billion pounds of rice husks are left over from rice processing in Bihar alone every year, a quantity large enough to allow the HPS founders to develop an electricity generation process based on this raw material (Greene, 2011). 
Since its founding in 2007, HPS has built 75 operational plants in Bihar which serve 150 villages, or a total of more than 150,000 people. The domino effects of bringing electricity to these areas are tremendous. HPS allows for villagers' activities to extend beyond daylight hourseconomic development and microenterprise is promoted and the amount of time children can study is increased. The reduction in pollution improves both air quality and overall health, and women spend less time collecting firewood, thus providing them with more time to participate in tasks that close gender inequality gaps. Reducing emissions and preventing deforestation protect both global and local environments, and improves overall health of local populations as well as increases the ease with which healthcare is administered.

In rural India, $45 \%$ of households-nearly 400 million people-lack access to electricity, and in states like Bihar, Orissa, and Uttar Pradesh (among the poorest in India), 80\%-90 \% of households have no electricity (Rohatgi, 2010). Villagers rely on kerosene lanterns for household light and diesel generators for irrigation and commercial power, but these traditional options are expensive and destructive to people's health and the wellbeing of the environment. Most of the units developed by HPS generate 32 kilowatts of electricity from $50 \mathrm{~kg}$ (110lb) of husks per hour, enough to provide the basic needs of a village of about 500 (Hanson, 2012). The cost of the service is about 80 rupees per month (less than $\$ 2.00$ ), about half the cost of the kerosene that most villagers use to power lamps that provide far less light than the 15-watt compact fluorescent lamps (CFL) bulbs distributed by the company (Boyle, 2010).

HPS has a goal: to provide electricity to 10 million people in over 10,000 villages by installing 3,000 plants by 2017 . If this goal is achieved, HPS will in the process give rise to 2,500 small entrepreneurs, and over 7,000 jobs will be generated in the communities it serves (Nadres, 2012). Utilizing existing local resources is both cost effective and a holistic way to approach the business product cycle.

\section{Green Technologies: powered by renewable resources-WE CARE Solar Suitcase: Lighting Delivery Rooms}

The WE CARE Solar Suitcase was developed after Laura Stachel, a doctor traveling in Nigeria, became aware of disturbingly high maternal and infant mortality rates in various areas of the country (Stachel, 2009). Doctors and midwives in developing countries often lack access to many of the essentials needed to properly care for patients-one of these is good lighting. Responding to this situation, a team of UC Berke- 
ley researchers from the Blum Center (along with Dr. Stachel) developed the "Solar Suitcase" as a viable solution.

Powered entirely by solar panels, the WE CARE Solar Suitcase contains the following equipment: bright LED lights, rechargeable walkietalkies and cell phone charger, and LED headlamps with rechargeable batteries (Dornhelm, 2010). In addition to significantly lowering the maternal mortality rate in rural regions of Africa, these elements have also proven to be absolutely critical in natural disasters such as the earthquakes in Haiti and Chile (Meehan, 2011).

While the WE CARE Solar Suitcases have saved thousands of lives during natural disasters and helped to lower maternal and infant mortality rates, the suitcase is quite heavy and requires several hours of direct sunlight to recharge the equipment (Erickson, 2010). Improvements are being made to make the suitcase lighter, more flexible, and even more durable so it can be a feasible solution for a deluge of other applications. Though the Solar Suitcase has been successfully assisting clinics after natural disasters and reducing mortality rates, and has proven to be revolutionary in developing countries all around the world, its potential has still not yet been fully realized (Callais, 2012). Demand for this technology is on a steady upward curve, and when supply becomes accessible to all populations that demand it, potential can be realized.

\section{Affordability: low input and operation costs-Jaipur Foot: $\$ 30$ Prosthetics}

The Jaipur Foot is one of the best examples of embodying the core competencies of Frugal Innovation to address global sustainability. The Jaipur Foot's main product offering is a rubber-based prosthetic leg for people with below-the-knee amputations. Originally distributed by the NGO Bhagwan Mahaveer Viklang Sahayata Samiti (BMVSS), the Jaipur Foot is now being used by the VA hospital in Palo Alto, CA and is also offered by Kaiser Permanente as an alternative to traditional prosthetics (Diaz, 2008).

The Jaipur Foot was developed in 1968 by Ram Chander (Sharma, 2011), and BMVSS was established in early 1975 by Mr. D. R. Mehta. In the first seven years after the development of the Jaipur Foot, 50 individuals were fitted with prosthetic legs and feet. Now, over 1.3 million beneficiaries of BMVSS - primarily in India but including 26 countries in Asia, Africa and Latin America-have been fitted with a Jaipur Foot prosthetic.

The biggest issue that the Jaipur foot takes into account is the need to be affordable-not cheapest in terms of cost, but highest in value-to- 
cost ratio (Craig, 2005). Victims of war crimes, patients who have suffered from infectious diseases, and people who have been in accidents who are now missing part or all of their leg(s) can now pursue lives that resemble normalcy. The Jaipur foot resembles a natural foot and leg, is able to be fully submerged in water (e.g., for working in rice fields), and is lighter in weight to allow for ease of movement and travel. Relative to a comparable prosthetic in the United States that costs $\$ 8,000$ and requires up to a year of recovery time, the Jaipur foot costs $\$ 30$ and has a rehabilitation time of 3-6 months (Chopra, 2004).

When considering how to address global sustainability issues via the core competencies of Frugal Innovation, the Jaipur foot is a wonderful example to keep in mind. Elements of all ten can be found in this one example, and it is prudent to hope that more examples will embody the excellence of Jaipur Foot's success (Co, 2008).

\section{CONCLUSION: APPLYING FRUGAL INNOVATION AND ITS CORE COMPETENCIES}

The first notions that typically come to mind when thinking about the term "Frugal Innovation" for the first time are "affordability" or "cheapness." In reality, however, the term refers to addressing the essence of a problem, and this focus on the essence of a problem is where the core competencies allow for truly novel innovations. If a solution is developed in alignment with the competencies depicted in this article, the solution will more properly address the needs of those targeted. Frugal Innovation, when pursued thoughtfully, results in high quality, applicable, accessible, and affordable services and products for consumers in emerging markets-and elsewhere.

Each competency opens a window of opportunity for those who exist in resource-constrained areas of the world. The cases discussed above illustrate clearly how these competencies can be brought to life; they are also examples of organizations, enterprises, and individuals that have created new standards for others to aspire to. The universality of benefit generated by these examples is what ties them all to the same theme-that of global sustainability and the role of social enterprises-and to all other organizations as well in contributing to a more sustainable world.

We urge people from all backgrounds and disciplines, regardless of profession, to seek an understanding of the needs of the developing world. By doing so, we can all move synergistically toward a more sustainable world. Frugal Innovation, when it is fully embraced, can be a firm driver of progress in achieving sustainable solutions. 


\section{REFERENCES}

Altenburg, T., \& Lundvall, B. 2009. Building inclusive innovation systems in developing countries: Challenges for IS research. In Handbook of innovation systems and developing countries: Building domestic capabilities in a global setting: chapter 2. Cheltenham, Glos, UK: Edward Elgar.

Ashden Awards Judges. 2011. ToughStuff International UK and Africa. The Ashden Awards, April 2011: http://www.ashden.org/files/ToughStuff\%20winner.pdf (accessed October 22, 2012).

Baiyere, A. 2011. Disruptive innovations at the bottom of the pyramid. In Hannu Salmela, Paul Laifa, \& Anne Rutkowski (Eds.), Dialogues Incubator, http:// www.dialoguesincubator.nl/wp-content/uploads/2011/07/Abayomi-BaiyereThesis.pdf (accessed Oct. 23, 2012). Netherlands: Tilburg University, Jan. 6.

Boyle, G. 2010. How to make electricity from rice husk. The Independent, December 2010: http://blogs.independent.co.uk/2010/12/10/how-to-makeelectricity-from-rice-husk/ (accessed October 24, 2012).

Callais, C. 2012. WE CARE Solar Suitcase shining brightly in rural health clinic. Blue News, October 2012: http://bluenews-blueenergy.blogspot.com/2012/10/ we-care-solar-suitcase-shining-brightly.html (accessed October 24, 2012).

Carless, J. 2007. Emergency responders rely on advanced technologies to help victims quickly, safely. The Network: Ciscos' Technology News Site, June 2007: http://newsroom.cisco.com/dlls/2007/ts_060807.html (accessed October 22, 2012).

Chang, A. 2010. Tata creates inexpensive water purifier. The Wall Street Journal, July 2010: http://online.wsj.com/article/SB100014240527487042936045753433 40396637802.html (accessed October 23, 2012).

Chopra, S. 2004. A foot-shaped miracle. Life Positive Chronicles, March 2004: http://www.lifepositive.com/Mind/Positive_Chronicles/A_foot_shaped_miracle. asp (accessed October 25, 2012).

Co, W. T. 2008. Jaipur Foot: Challenging convention, June 17, 2008: http://itethic. pbworks.com/w/page/20191038/Jaipur\%20Foot (accessed October 25, 2012).

Craig, J. 2005. Prosthetic feet for low-income countries. American Academy of Orthotists and Prosthetists, 2005: http://www.oandp.org/jpo/ library/2005_04S_047.asp (accessed October 25, 2012).

Devi, T. 2012. A better harvest for Indian farmers: Just a phone call away? Center for Microfinance, April 2012: http://centreformicrofinanceblog.wordpress. com/2012/04/09/a-better-harvest-for-indian-farmers-just-a-phone-call-away/ (accessed October 24, 2012).

Diaz, J. E. M. 2008. Jaipur Foot: Challenging convention. Jenneddendiaz, 2008: http://jenneddendiaz.pbworks.com/w/page/11626918/Jaipur\%20Foot (accessed October 25, 2012).

Dornhelm, R. 2010. Solar Suitcases travel to the world's powerless. NPR, May 2010: http://www.npr.org/templates/story/story.php?storyId=126453393 (accessed October 24, 2012).

Erickson, C. 2010. WE CARE Solar: A suitcase-size solution to reducing maternal mortality. Ashoka Changemakers, June 2010: http://www.changemakers. 
com/stories/we-care-solar-suitcase-size-solution-reducing-maternal (accessed October 24, 2012).

Govindarajan, V., \& Ramamurti, R. 2011. Reverse innovation, emerging markets, and global strategy. Global Strategy Journal, 1: 191-205.

Greene, K. 2011. Husk power lights rural India. Giga, August 2011: http://gigaom. com/cleantech/husk-power-lights-rural-india/ (accessed October 24, 2012).

Hanson, S. 2012. Energy for the masses: Husk power helps fuel India. Renewable Energy World, January 2012: http://www.renewableenergyworld.com/rea/ news/article/2012/01/energy-for-the-masses-husk-power-helps-fuel-india (accessed October 24, 2012).

Hart, S. L., \& Christensen, C. M. 2002. The great leap: Driving innovation from the base of the pyramid. MIT Sloan Management Review, Fall 2002: http:// impactinvestor.eu/wp-content/uploads/2011/02/Hart-Christensen-2002-Thegreat-leap.pdf (accessed Oct. 23, 2012).

Heatwole, A. 2011. Calling it in: Awaaz.De provides a voice-based information platform. Mobile Active, November 2011: http://www.mobileactive.org/callingit-in-awaazde (accessed October 24, 2012).

Johansson, A., Guillemette, Y., Murtin, F., Turner, D., Nicoletti, G., de la Maisonneuve, C., Bousquet, G., \& Spinelli, F. 2012. Looking to 2060: Long-term global growth prospects: A going for growth report. OECD Economic Policy Papers, 3.

Kopo Kopo. 2011. Kopo Kopo helps bring mobile microfinance to Sierra Leone. Mobile Financial, February 2011: http://www.mobile-financial.com/news/ kopo-kopo-helps-brings-mobile-microfinance-sierra-leone (accessed October 24, 2012).

Lavallee, A., \& Veach, E. 2010. Tata water purifier wins the top prize for novel product. The Wall Street Journal, October 2010: http://online.wsj.com/ article/SB10001424052702304388304575574022361799134.html (accessed October 23, 2012).

Makarechi, K. 2011. Katherine Lucey brings solar light to rural East Africa (HuffPost Greatest Person of the Day). Huffington Post, October 2011: http://www. huffingtonpost.com/2011/08/10/huffpost-greatest-person-katherine-lucey-solarsister_n_923691.html (accessed October 23, 2012).

Making It. 2011. Solar Sister: Empowering women with light and opportunity. Making It Magazine, September 2011: http://www.makingitmagazine. net/?p=4105 (accessed October 23, 2012).

Marlow, J. 2009. Bringing low-cost solar to the world's poor. The New York Times, October 16, 2009: http://green.blogs.nytimes.com/2009/10/16/bringing-lowcost-solar-to-the-worlds-poor/ (accessed October 22, 2012).

Matthews, C. 2008. Better than government? New ways to deliver services to India's poor. Institute of Development Studies, October 2008: http://www.ids. ac.uk/news/the-naandi-foundation-ceo-lecture (accessed October 23, 2012).

Meehan, C. 2011. WE CARE Solar wins humanitarian technology award for Solar Suitcase. Clean Energy Authority, October 2011: http://www. cleanenergyauthority.com/solar-energy-news/we-care-solar-wins-award-forsolar-suitcase-102811/ (accessed October 24, 2012). 
Microfinance Africa. 2011. Interview with Kopo Kopo. Microfinance Africa, April 2011: http://microfinanceafrica.net/interviews/microfinance-africa-interviewwith-kopo-kopo/ (accessed October 24, 2012).

Misra, N. 2011. Solar Sister: Bringing a market based, gender inclusive, bottom up clean energy revolution to Africa. Development Marketplace, June 2011: http://blogs. worldbank.org/dmblog/solar-sister-bringing-a-market-based-gender-inclusivebottom-up-clean-energy-revolution-to-africa (accessed October 23, 2012).

Musich, P. 2007. NetHope brings fast links to disaster relief. EWeek, December 2007: http://www.eweek.com/c/a/IT-Infrastructure/NetHope-Brings-Fast-Linksto-Disaster-Relief/ (accessed October 22, 2012).

Nadres, L. 2012. IFC report highlights Husk Power Systems as a business that creates opportunity at the base of pyramid. International Finance Corporation, October 2012: http://www.ifc.org/ifcext/pressroom/IFCPressRoom.nsf/0/91AFB A5DD4CDBAE085257A93004CBDA3 (accessed October 24, 2012).

Neil, P. 2011. Awaaz.De data sheet. Mobile Active, November 2011: http:// mobileactive.org/mobile-tools/awaazde (accessed October 24, 2012).

Nijhof, A., Fisscher, O., \& Looise, J. K. 2002. Inclusive innovation: A research project on the inclusion of social responsibility. Wiley InterScience, Mar. 5, 2002: http://onlinelibrary.wiley.com/store/10.1002/csr.10/asset/10_ftp.pdf?v=1\&t=ha971 4zc\&s=1f062d5e94cc6ffafb5510e3adb6d01458267754 (accessed Oct. 23, 2012).

Nunziata, S. 2010. Geeks for Haiti work to restore communications. Mobile Enterprise, January 2010: http://mobileenterprise.edgl.com/top-stories/ Geeks-For-Haiti-Work-To-Restore-Communications60880 (accessed October 22, 2012).

Peck, E. 2010. NetHope's "Network Relief Kit" fits in a backpack! Immovative Interactivity, May 2010: http://www.innovativeinteractivity.com/2010/05/12/ nethope-network-relief-kit/ (accessed October 22, 2012).

Prahalad, C. K. 2005. The fortune at the base of the pyramid: Eradicating poverty through profits. Philadelphia, PA: Wharton School Publishing.

Prahalad, C. K., \& Mashelkar, R. A. 2010. Innovation's holy grail. Harvard Business Review, July-August: 132-141.

Radjou, N., Prabhu, J. C., \& Ahuja, S. 2012. Jugaad innovation: Think frugal, be flexible, generate breakthrough growth. San Francisco, CA: Jossey-Bass.

Rohatgi, M. 2010. Turning abysses of darkness into islands of light. MIT Technology

Review India, June 2010: http://www.technologyreview.in/energy/25412/ (accessed October 24, 2012).

Sandell, M. 2012. Kopo Kopo helping Kenyans pay by mobile phone. Sustainable Brands, March 2012: http://www.sustainablebrands.com/news_and_views/blog/ kopo-kopo-helping-kenyans-pay-mobile-phone (accessed October 24, 2012).

Sharma, A. 2011. Stepping into new life with the Jaipur Foot. Overseas Indian, 2011: http://www.overseasindian.in/2006/oct/news/21fea5.shtml (accessed October 25, 2012).

Singh, S. 2011. Tata Chemicals' formula. Forbes, August 2011: http://www.forbes. com/2011/08/01/forbes-india-tata-chemical-formula-making-health-wellnessproducts.html (accessed October 23, 2012). 
Sinsky, R. 2011. "The wallet is dead," and Kopo Kopo is digging its grave. Venture Beat, July 2011: http://venturebeat.com/2011/07/13/the-wallet-is-dead-andkopo-kopo-is-digging-its-grave/ (accessed October 24, 2012).

Solar Sister. 2012. Solar Sister's energy consignment model. Arc Finance, July 2012: http://www.arcfinance.org/pdfs/pubs/Arc\%20Finance_Case\%20Study_Solar\%20 Sister_2012.pdf (accessed October 23, 2012).

Stachel, L. E. 2009. WE CARE Solar. Blum Center Developing Economies, September 2009: http://blumcenter.berkeley.edu/global-poverty-initiatives/energyefficient-technologies/maternal-child-health (accessed October 24, 2012).

Subbu, R. 2009. Low cost water purifier from Tata Chemicals. The Hindu, December 2009: http://www.hindu.com/2009/12/08/stories/2009120856891400.htm (accessed October 23, 2012).

Sullivan, A., \& Sheffrin, S.M. 2003. Economics: Principles in action. New Jersey: Pearson Prentice Hall.

Tiwari, R., \& Herstatt, C. 2012. India-A lead market for frugal innovations? Extending the lead market theory to emerging economies. TIM/TUHH Working Paper No. 67, January 2012. Available at SSRN: http://ssrn.com/ abstract=1998411 or http://dx.doi.org/10.2139/ssrn.1998411.

ToughStuff. 2010. What is ToughStuff? ToughStuff Online, 2010: http://www. toughstuffonline.com/pages/what-toughstuff-0 (accessed October 22, 2012).

The Trickle Out Project. 2012. ToughStuff Solar. Economic and Social Research Council: http://trickleout.net/index.php/casestudiesmainmenu/ toughstuffmenu (accessed October 22, 2012).

Vousvouras, C. A., \& Heierli, U. 2010. Safe water at the base of the pyramid. 300in6 Initiative, August 2010: http://www.aqua4all.nl/documents/aqua4all/ downloads/safe-water-at-the-base-of-the-pyramid-booklet.pdf (accessed October 23, 2012).

Wavelength Issue No. 3. 2009. Meet William Brindley, Chief Executive Officer and Executive Director of NetHope. ICT: Humanitarian Emergency Platform, September 2009: http://ictemergency.wfp.org/web/ictepr/meet-william-brindley (accessed October 22, 2012).

William Davidson Institute. 2009. Bringing safe water to India's villages and communities: The Naandi Foundation. GlobaLens, December 2009: http:// www.globalens.com/DocFiles/PDF/cases/inspection/GL1428987I.pdf (accessed October 23, 2012).

Zeschky, M., Widenmayer, B., \& Gassmann, O. 2011. Frugal innovation in emerging markets: The case of Mettler Toledo. Research-Technology Management, 54(4): 38-45. 